\title{
Language Shift From Arabic Into English With Regard to Techniques of Borrowing and Arabicization: An Empirical Study
}

\author{
Abdullah K. Shehabat \\ Correspondence: Abdullah K. Shehabat, Tafila Technical University, Jordan. \\ Received: February 2, 2021 \\ Accepted: February 21, 2021 \\ Online Published: March 27, 2021 \\ doi:10.5430/elr.v10n1p29 \\ URL: https://doi.org/10.5430/elr.v10n1p29
}

\begin{abstract}
Due to the unexpected number of languages that are anticipated to be lost during the next century, the present paper investigates the matter of language shift in a bilingual speech community with regard to the techniques of borrowing and Arabicization. Twenty-six Arabic contexts with loanwords and/or Arabicized items were provided to Arabic and English linguists who were asked to judge the level of acceptability and readability of them. A google forms questionnaire was used as a tool to conduct this empirical study. We found that there is a general tendency towards rejecting the items that have a foreignized sense unless the alternatives function similar to the original ones. However, some subjects valued the responses that captured the communicative sense of the original message. In the meantime, we listed the sociolinguistic factors that play a major role in creating language shift along with their influence on Arabic language.
\end{abstract}

Keywords: language shift, borrowing, Arabicization, language persistence, domesticized sense, communicative sense, foreignied sense

\section{Introduction}

In a bilingual speech community and with the advance of technical and digital life along with peoples' desire to keep up with whatever is new, people shall expect the birth of new, somehow technical, expressions that trigger a challenge for language users, and eventually translators, especially within interlingual contexts. This linguistic phenomenon is referred to as language change and/or interference that results due to shifting among languages. It is a result of people's interaction with technology and the changing life style that automatically help create changes on the phonetic and phonemic structures. Kandler and Steele (2017) explain that such phenomenon is normally a result of processes of "globalization, urbanization and long-distance economic migration" (4851). Versteegh (2001) also shows that this linguistic phenomenon typically increases because speakers of the local language are always in touch with speakers of other languages (XLVIII).

Language shift and, accordingly, language death (or extinction) have recently become one of the heated topics among linguists and translators, as well. Therefore, if, according to Versteegh (2001), this shift is complete then the local language becomes a subject either to perish or to extinct (XLVIII). Grenoble and Whaley (1998) have thoughtfully elaborated on how relevant this subject could be to language survival. They explained that once the process of language shift begins, then it is axiomatic that the language loss, extinction or even death is bound to occur. Similarly, from a translation perspective, it is common to face problems when translating texts that include such expressions due to their unfamiliarity in the TL. However, with the availability of high-tech means of data providers and linguistic specialized thesauruses, it has become easier to capture the communicative sense of such newly-born terms. This interaction sometimes occurs due to people's constant search for ease in passing on information by borrowing lexical items from other languages, coining these items or making up their own. Additionally, often the language seen as more modern, useful, or giving access to greater social mobility and economic opportunities is chosen as the lingua franca, thereby driving the process of language shift (Grenoble and Whaley 27).

The rationale behind this empirical study stems from the pressing need to preserve Arabic language from loss and extinction due to the anticipated death of languages in the next century (Grenoble and Whaley 23). Furthermore, we need to point out that Arabic language, according to Salloum and Peters (1996), is ranked the "seventh on the list of languages that has contributed to the enrichment of the English vocabulary" (xii). By and large, the present study aims to examine the phenomenon of language shift in a bilingual speech community where a language shift to a dominant language has become remarkably observed. To measure the impact of the language shift between Arabic language and 
English language, the responses of Arabic speakers in terms of the items' level of acceptability and readability will be scrutinized. It is pivotal to emphasize the fact that linguistic shift by default becomes more influential when linguists or speakers improperly use and/or acquire the language. However, the notion of referring to languages as colonized and the way they were looked at from that viewpoint was ignored as it would enlarge the horizon of the current study.

Kandler and Steele (2017) define language shift as "the process whereby members of a community in which more than one language is spoken abandon their original vernacular language in favor of another" (4851). Likewise, Fishman (1991) defines it as a "process whereby intergenerational continuity of the heritage language is proceeding negatively, with fewer 'speakers, readers, writers, and even understanders' every generation" (1). Language shift, as far as the present paper is concerned, means switching into another language while attempting to communicate an idea using one's mother language either because the speaker is unable to find the appropriate expression in the same language or because he thinks that the expression in mind might not sound proper enough, or that he wants to show that he is highly intellectual by switching between more than one language at atime.

It is worth mentioning that the linguistic terminologies in the current study, language shift or Arabicization and borrowing, share a distinctive feature in identifying the relationship between the local language and the community where it is spoken and how they affect one another. This explains the authors' intent in choosing more than one linguistic term to refer to the matter of switching between languages. For example, Al-Mazrouei (2014) defines Arabicization as a "language planning process...that studies the relation between language and society and the way they affect each other" (cited in Al-Ajrami 1989). Likewise, in their book Language Contact, Creolization and Genetic Linguistics, Thomason and Kaufman (1988) consider borrowing "a type of change where foreign elements are incorporated in the speaker's native language" (21-22). Further, while Newmark (1988) defines borrowing in terms of the conversions that take place between two languages with a lexical gap between them (81), De Corte (2003) refers to it as a procedure that normally serves to fill a lexical gap, [and] enriches the [local or source] language" (70).

One way or another, the definitions above share the idea that during daily conversations, whether in academic circles or during people's ordinary talks, it is pivotal to always keep local languages intact, especially in bilingual speech communities. That is to say, local languages in a bilingual speech community shall be devoid of linguistic predators, which are always viewed as being dominant, to ensure maintaining what Hale et al. (1992) termed "linguistic diversity," a term they referred to to make sure that local languages are well-preserved along with their cultural systems. For them, "any loss of linguistic diversity will automatically result in a loss of the components of "human mental industry" (36).

When it comes to the subject of language shift and/or interference between Arabic language, the local language, and English language, the dominant one, it can be noticed that there are plenty of studies that tackled it (cf., Kandler and Steele (2017); Fishman (1991); Hale et al. (1992)). However, very few of these studies have dealt with terms and expressions that are observed in people's daily discourse where Arabic language functions as the local language and English language functions as the dominant one. This current study examines a number of loanwords and/or Arabicized expressions that have, intentionally or unintentionally, been used in Arabic language conversations. Later, we will measure the levels of acceptability and readability.

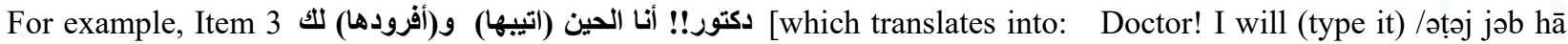
/and (forward it) /afor wod dha/ to you] is an expression said by a secretary, a Bahraini girl, addressing her Head of Department that she will type a document and send it to him via email ${ }^{1}$. Undoubtedly, there is no Arabic word like اتيبها which literally translates into (I will type it) and بفرودها which literally translates into (I will forward it) but apparently the overuse of these expressions in the secretary's daily conversations made them comprehensible and acceptable for communication.

\section{Method}

\subsection{Data Collection}

The data for the current study will be collected from people's daily conversations, mainly in the post of COVID-19, where, roughly speaking, most academic institutions have been turned to virtual cells. The overuse of technical and sociocultural expressions in daily conversations has distinctively characterized this period, especially in social media, academic institutions and training centers. Additionally, observing people's daily conversations has enriched our data and provided people with proper examples that will unquestionably be very convenient for the present study.

1 The conversation is conducted between one of the authors who worked for one of the universities in Kingdom of Bahrain with his secretary who is supposed to type some official documents. The names will not be declared for academic research purposes and work ethics ones. 
In addition to the expressions that have extensively appeared in the post of COVID-19, people at work and in social life have started to arabicize a number of technical terms and also to use a number of new loanwords. The issue here is that these terms have been dependably used in the local language, whether written or spoken. While Observing people at work and in certain situations of academic life in other institutions, 26 expressions were elicited. Categorized and listed in a questionnaire with open and closed questions, those items were sent via google documents to instructors and professors majoring in English and Arabic (See Appendix A).

\subsection{The Instrument}

Due to the current situation of COVID-19 where communication via paperwork is not likely and risky, the questionnaire was sent via google documents to the respondents. To evade confusion and to facilitate their task, the respondents were provided with the sociocultural contexts where the expressions were elicited. Doing so, it was intended to ensure whether or not these expressions read natural and comprehensible as originally intended by the local speakers. The questionnaire asks respondents to identify the best category that matches with the item in italics and later to jot down the rationale behind their choice. All respondents' names and personal information will not be revealed during the study for privacy reasons (See Appendix A).

\subsection{Participants}

The questionnaire was also given to 20 instructors and professors who have broad background in English language and Arabic language, as well. As diagram 1 shows, the distribution of the area of specialization shows that 15 out of 20 are majoring in translation studies and English related majors. The rest, whom the researcher knows pretty well through virtual translation seminars and webinars, have got a broad expertise in Arabic language studies. The respondents' major task will be to judge each item within its normal context: whether or not it is acceptable and readable, moderately acceptable or even rejected. It is axiomatic, though, that if the item in question is neither readable nor acceptable then its translatability ratio would be limited. We will further discuss the criteria upon which the respondents had established their responses. We will not ask the respondents to translate these expressions because these expressions are originally loanforms taken from English. However, a suggested substitution will be provided for some of the unfamiliar and culture-oriented expressions and newly-born ones.

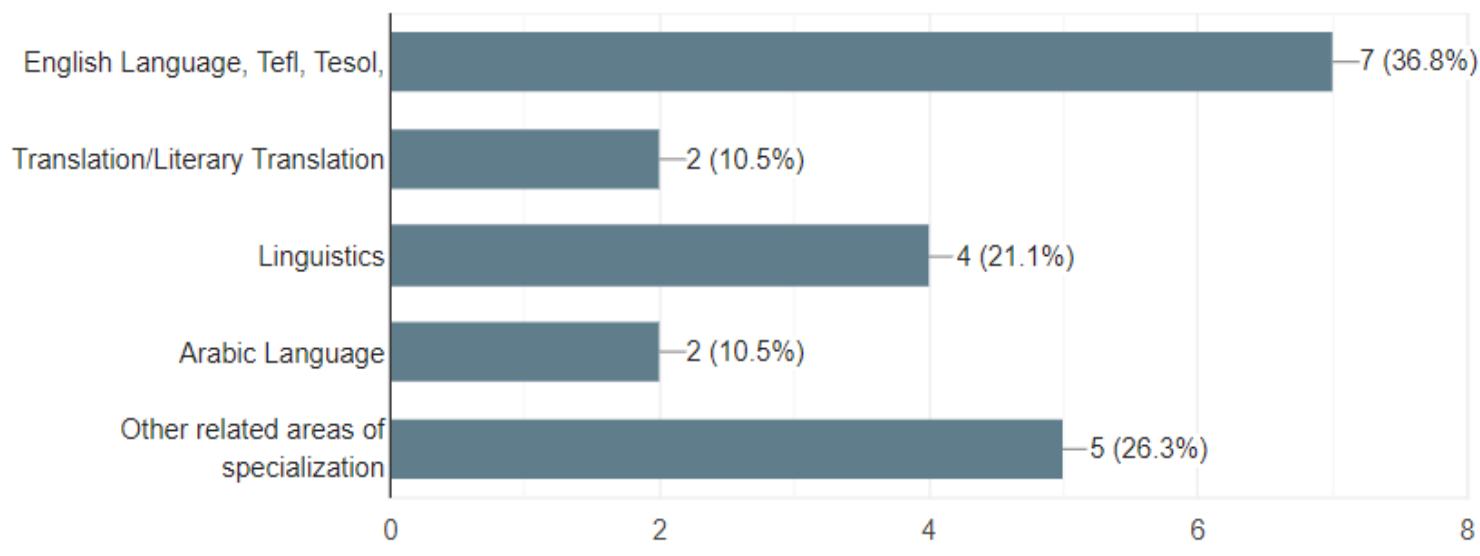

Diagram 1. Distribution of Respondents in light of the Area of Specialization

\section{Discussion}

The process of analysis will be threefold: the first will explore the highest levels (percentage) of acceptability and readability, the second will deal with the highest levels (percentages) of unreadability and unacceptability whereas the third will deal with the items totally rejected. Throughout the process of discussion and analysis, items will be provided with their percentages. Achieving high percentage of acceptability and readability means that the items can be justifiably used in peoples' daily communication, even among academic circles. In contrast, achieving low percentages of acceptability and readability means that those terms are not supposed to be used in people's daily communication and should be replaced by better synonyms that could capture the spirit of the intended message. As for the third group, the items that score a high percentage in terms of capturing the message will be considered.

Linguists, according to Priestly (2003), recognize that "frequency of use, proficiency, and perceived value" are among the most important factors that markedly affect the perseverance of languages or even their extinction (97). Here, the major objective in our discussion is to make sure that the mother language (here Arabic language) is preserved during 
the process of language shift. Also, we need to emphasize the notion that the level of perseverance and persistence of language is measured via the appropriate level of acceptability and readability by linguists and language users. To do so, we will explain the context in which each item was used. The major criterion on which the subjects will base their responses will be the communicative value of the item.

\subsection{Acceptability and Readability}

By acceptability and readability, we mean that the respondent does not get confused when s/he reads the terms and/or hears them. Also, s/he must understand the intended message as soon as $\mathrm{s} /$ he reads the expressions without any misperception of apprehending their semantic and phonetic units. Friedrich Schleiermacher (2000) stressed the significance of having a readable text after any transmission process that takes place between any two languages. He explained that there is an indispensable difficulty that is related to the matter of receptiveness of the local language. That is, if the readers or linguists appropriately comprehend and/or receive the original message of the local language, then the process of receptiveness is legitimate and fair (53). These two terms are interrelated; if one is acceptable then by default it will be readable. So, the major criteria in judging these terms will primarily depend on the respondents' own assessment. Table 1 below displays the subjects' responses to the fully acceptable and readable items.

Table 1. Responses of Fully Acceptable and Readable Items

\begin{tabular}{|c|c|c|c|}
\hline TheContext & 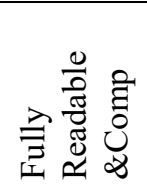 & The Context & 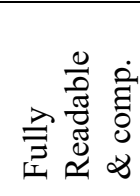 \\
\hline 1. عي هويلنوطول الليل (بيستر)مع صييته & 10.5 & 14. لا تنسى (تسسيفي) اللي طبعتيه & 36.8 \\
\hline 2. و اللهيامعلم لقيو اولحدكورنومتخبي & 21.1 & 15. ايطاليا بلاد (الانتيكات) لازم نزور ها & 42.1 \\
\hline 3. ككورب! أنا لين (تنيها) و(أفرودها)لك & 5.3 & 16. و لا شار ع (مسفلت).. كلها مكسرة. & 26.3 \\
\hline 4. طولنهره (يككن) مع الصبيا & 10.5 & 17. روح لعند المالية الان (بكيشوك) & 5.3 \\
\hline 5. يبيو ان (البج) ماراحتسمح هذا العلم & 10.5 & 18. هيوه موجود بالجامعه بس (ييركن) السيارة & 15.8 \\
\hline 6. حكلي السكرتبيرة (كيبه) ولشهابصنليق البريد. & 10.5 & 19. مصطلح ما بتفهم معناه (غو غله). & 10.5 \\
\hline 7.ببي الروح (تشرج) اللتون...ماضلفيهرصيد & 10.5 & 20. سيفه وحط الايقونه على (الدسك توب) & 42.1 \\
\hline 8. لغزفة هني لازم(تنكش).ولجدر!! & 31.6 & 21. كنت العب (قولجي) مع فريق الجامعة. & 21.1 \\
\hline 9. لازمتزوحين طى (يوتيستزر) & 21.1 & 22 صار كناز زمان نستخدم (السمارت بورد).. الان كله & 26.3 \\
\hline 10 الخوي اليوم(يز) على لمريكا & 57.9 & 23. مش لازم تمشي بالممر ات بدون (الماسك) & 21.1 \\
\hline 11. بعث ليمبل للمدرسبن اللي غناكو (سسيني) & 10.5 & 24. معقولة يحسبولنا هذا الثغل (اوفر تايم). & 42.1 \\
\hline 12. الولدكان خلف من لوه ..شكامسكه (يككن) مع بنت. & 15.8 & 25. قبل ما ييلش الاجتماع تاكد من (السبيكرز) & 15.8 \\
\hline 13. هو يحلول أن (يؤلج) جيع ألافكل & 21.1 & 26. اياها. مش قادر اقرأ الخط بتقدر تكبشر ها ونتبعثلي & 5.3 \\
\hline
\end{tabular}

As the table 1 above shows, there is a consensus on the lack of readability and comprehensibility levels for all items in question except for item 10 that scored 57.9 \% of readability and comprehensibility. This item, فوي اليوم (فيّز) على امريكا, /fay yaz/ [which literally translates into: My brother has got a visa to USA today] is commonly used in Arabic language discourse to the extent that very few people recognize it as being derived from the English noun Visa. The linguistic shift that resulted here, i.e., shifting from Arabic into English, resulted from speakers' tendency to transfer the phonological features from their native language i.e., Arabic into English (Versteegh 473). So, it goes without saying to use it in daily conversations due to its common usage, feasibility and brevity. It is apparent that people prefer using حصل على تأثيرة سفر which is lengthy in utterance. Here, speakers of Arabic language would inadvertently resort to this expression possibly because the term captures the message to a great extent by rendering the semantic unit of the original (see Diagram 2). 


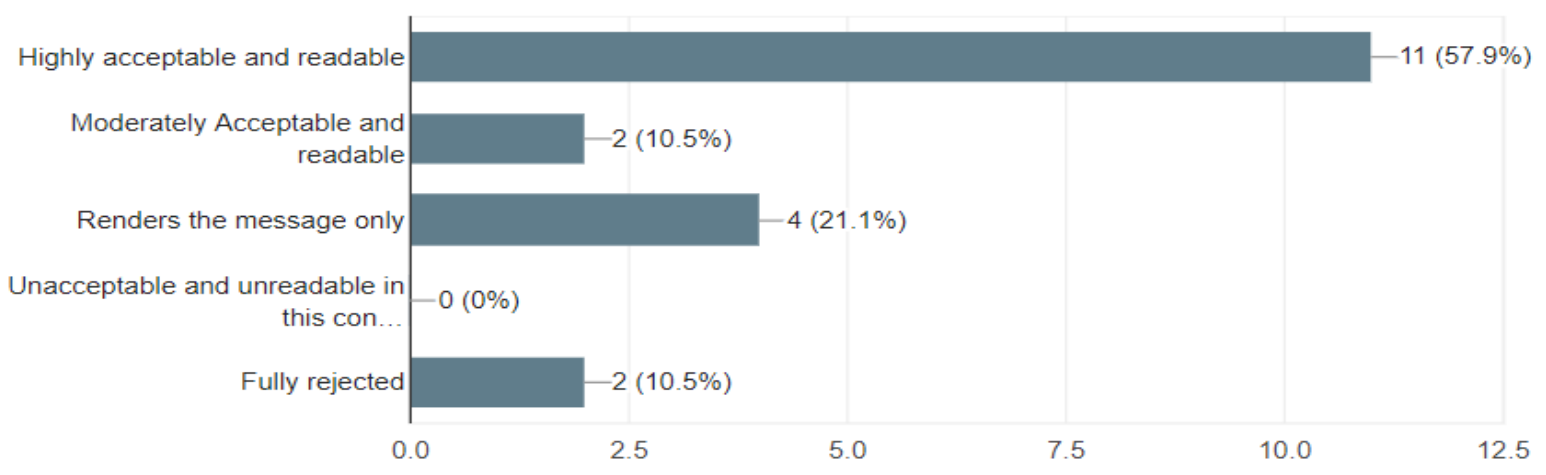

Diagram 2. Detailed responses for Item 10

What also supports our previous argument from Diagram 2 is that none of the respondents considered Item 10 as 'unacceptable and unreadable' in the context provided although it is an Arabicized term taken from English language. This percent represents a great match with the level of highly acceptable and readable criteria which ensures that the respondents were aware of the task and that their responses were accurate. The lexical choice of the term sounds natural in that context due to being extensively used by people. In consequence, people have become accustomed to pronouncing its phonetic structure, therefore accepting it the way it is articulated.

However, none of the remaining items in Table 1 scored a satisfactory level of acceptability and readability. Only three items $(15,20$ and 25 , respectively) altogether scored $42.1 \%$ while the others scored very low level of acceptability and readability ranging from $42.1 \%-5.3 \%$. This means that English and Arabic specialists strongly reject using these expressions in people's communication even when the communicative value is not lost. The respondents provided some justifications for why borrowing technique is not appropriate. They mentioned that

- The highlighted expressions are unfamiliar and not as good as the original.

- They look mechanical rather than Arabic.

- They cause distortion to the language and its beauty.

- They affect the spirit of the meaning.

- $\quad$ They don't look like Arabic despite written with Arabic Alphabets.

- $\quad$ They make no sense in those particular contexts.

Notably, although the remaining items fall within the category of low level of acceptability and readability, we still notice that we have two main categories that are worth to distinguish. The first can be classified as higher-low while the second category can be classified as lower-low. The former refers to the group whose items are very frequent and common in Arabic language. In other words, due to the extensive use of these items among people, they have become very familiar but not fully acceptable nor readable. Examples are فئرئ....etc. A major explanation for scoring slightly better than the other group is that the Arabic equivalence for some of these expressions do not have one-word-synonym that renders its meaning. Instead, Arabic language users need to define these words so as to render their meanings. For example, it is easier to refer to Item 16, the French coined word context rather than to define its meaning in the same Arabic context.

$$
\begin{aligned}
& \text { - لا يو لا وجد اي شارع مُسفْلت في المنطقة }
\end{aligned}
$$

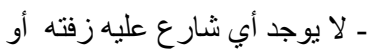

$$
\begin{aligned}
& \text { - لا يوجد أي شار عُعُعد بالزفتة. }
\end{aligned}
$$

Here, for the Arabic learners and users, as well, using the Arabicized form مُسفظلت /Mosaflat/is easier for communication once they want to refer to "asphalt". This explains why this expression has scored a slightly moderate percent of acceptability and readability with $26.3 \%$. (See Diagram 3). However, the second two options which came in the form

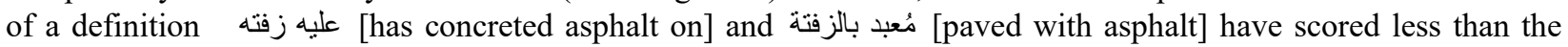
foreignized term due to their unfamiliar usage within the Arabic context. Although the phrase مُعبد بالزفتة makes a lot of sense and is standard in Arabic language but the thing is that the Arabic word زفت ز has got a negative connotation 
in all Arabic contexts. This also explains why people may not resort to using this expression in their daily conversations although it might render the intended message. It further clarifies why people prefer to resort to short forms rather than long phrases and definitions.

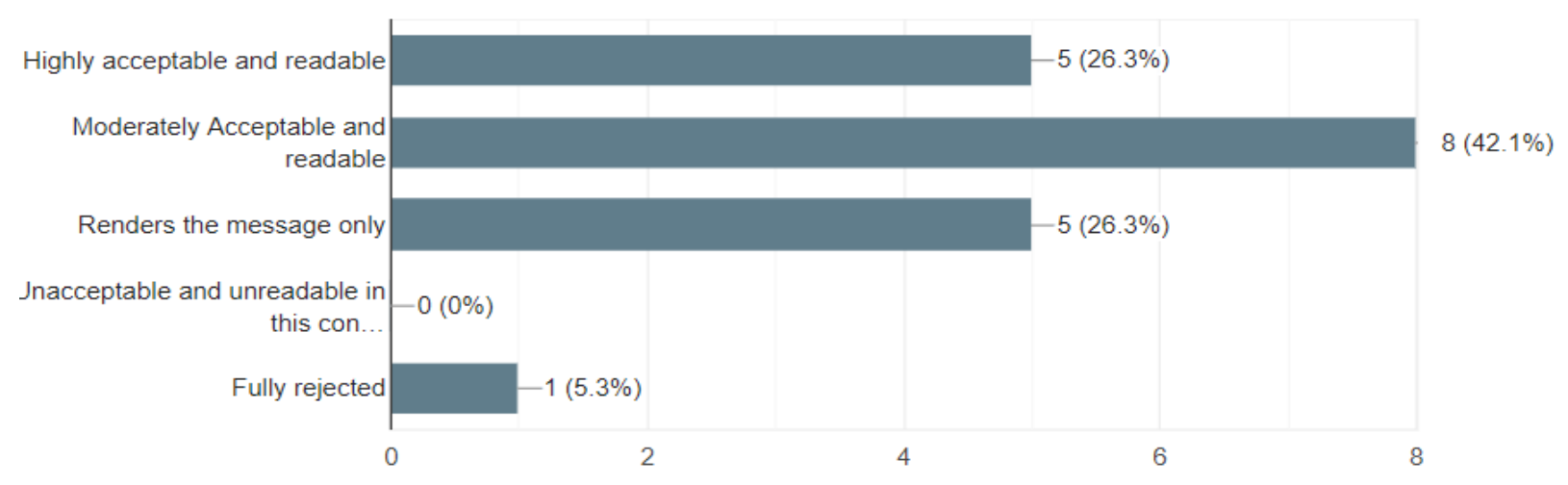

Diagram 3. Detailed responses for Item 16

The latter, on the other hand, refers to the expressions which scored lower percentages of acceptability and readability, meaning that they are fully unacceptable and unreadable and thus should be declined. For example, the Arabic

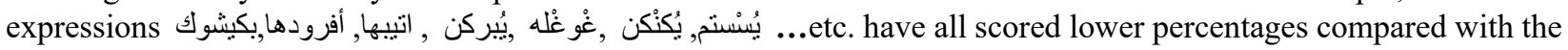
other group. These expressions may well sound odd in any natural discourse due to their unfamiliar phonetic and phonemic structure that can be observed. However, people insist on using them in their daily conversations. Once asked about their opinions for why people may well keep using these expressions despite sounding neither acceptable nor readable in a natural Arabic context, the subjects mentioned that

- $\quad$ These expressions communicate the message clearly and easily.

- They don't have a better alternative/ they are unfamiliar with their Arabic synonyms.

- $\quad$ These expressions are short and brief.

- $\quad$ They match with people's communication in such technical-oriented life.

- $\quad$ They heard other people use these expressions.

Item 17, (بكيشوك) /bi kəj šūk/ which literally translates into [they'll give you cash] scored only 5.3\% (See Diagram 4). 2 respondents with $10.5 \%$ fully rejected this term to be used in a natural Arabic discourse because of being Arabicized. This means that this term is declined among people whose backgrounds are in linguistics, literary studies, translation and Arabic studies. Here, a better synonym that substitutes the phrase سيعطوك نقد which is straightforwardly understood although it carries no ambiguous meaning. However, the point, according to one of the respondents who supported using this term, is that the phrase سيعطو ك نقدا is a standard phrase that sounds inappropriate within a colloquial context and sounds funny in a daily conversation. Despite this one reservation, we believe that as long as there exists a suitable Arabic replacement and/or phrase for item 17, there will be no need to look for a loan expression and/or an Arabicized term. A major reason is that the voicing of the phraseology sounds hard, if not imperceptible, for Arabic as well as English speakers and users. 


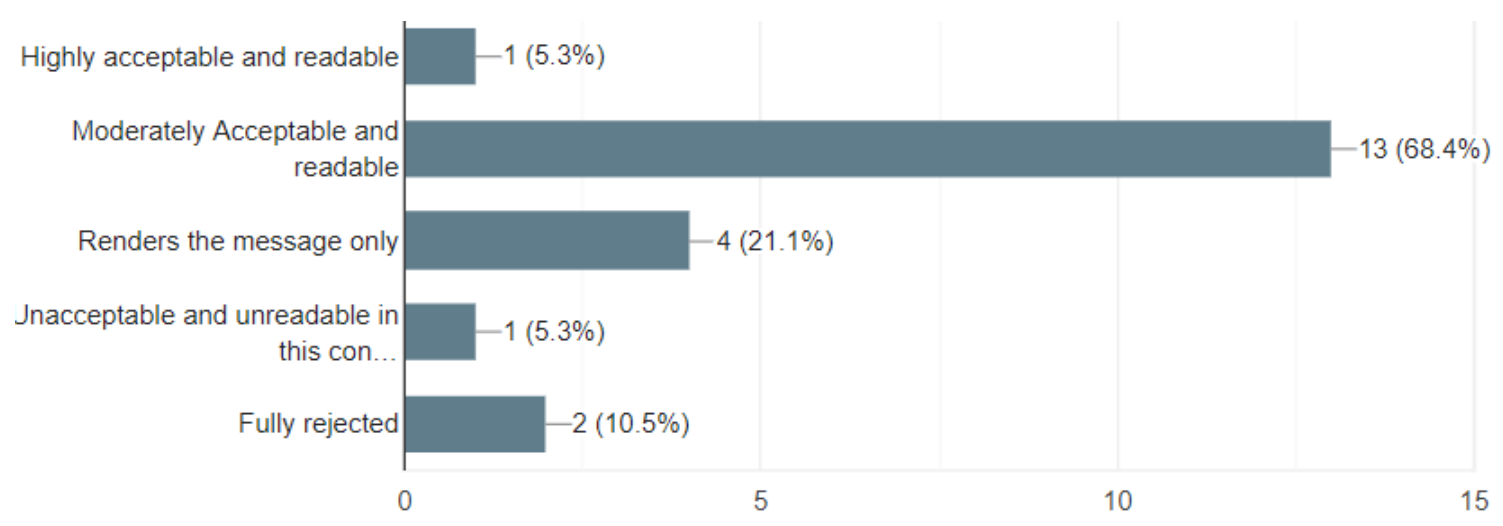

Diagram 4. Detailed responses for Item 17

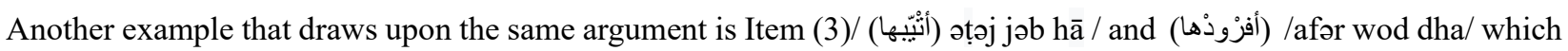
translates into: Doctor! I will (type it) and (forward it) to you. Believing that the message will be transferred quickly and accurately, the speaker, a secretary in one of the Academic institutions in the Kingdom of Bahrain, resorts to an Arabicized word although she is cognizant that there is a better yet more accurate synonym for these two transitive verbs. Once asked about her choice of these two verbs in particular, she said that it was the way other secretaries pronounce them since she began her work. Also, she mentioned that she was aware of the Arabic synonyms for the two verbs but because she felt that it is reasonable to keep using these verbs the way she used to in her daily conversation. She eventually explained that the Bahraini dialect requires girls to be more elegant in dealing with such expressions because $b / t /$ in Arabic is a bit heavy to pronounce and sounds like vulgar.

Apparently, the level of acceptability and readability of Item 3 is very low with 5.3\%. Most responses revolved around either rendering the message only or being unacceptable and unreadable in the context provided (See Diagram 5). Those who accepted the use of these two expressions in that particular context have valued the communicative role to the structural unit of meaning. Furthermore, $15.8 \%$ of responses fully rejected using the loan forms of (əțj jəb hā )and (a fər wod dha) for the sake of personal communication. All in all, it can be noticed that the respondents did not like using these two expressions in their daily communication but they only accepted them as valuable sources in communication.

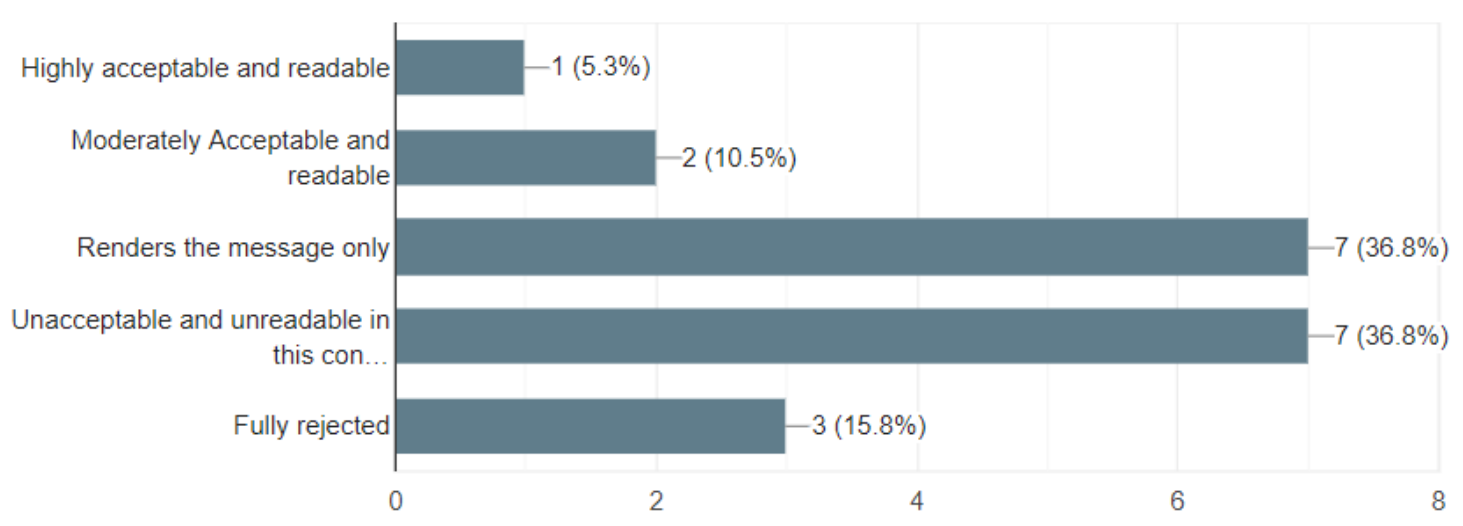

Diagram 5. Detailed responses for Item 3

When asked about their justification for rejecting these two expressions to be used within their Arabic contexts, the respondents provided the following reasons:

- They don't read Arabic.

- They don't sound familiar.

- They are hard to hear for an Arabic ear. 
- $\quad$ They may sacrifice the spirit of the meaning.

- Arabic language is rich with better expressions, so it is preferable not to use them.

In addition to the reasons above, we argue that resorting to verbs into a phrase like [forward] يعيد ارسال or يعيد توجيه and [type] بطبعها makes the message more comprehensible, readable and eventually more acceptable. So, it can be inferred that the borrowing technique fails to a large extent to capture the linguistic and semantic unit for the terms in question. In other words, resorting to the real synonyms of يطبع يطيد ارسال and يطب would sound more genuine and more convincing.

The last example in the first group is Item علي هويان وطول الليل (يُستن) مع حبييته1 which translates into [Ali is in love and he spends the whole night flirting his girlfriend]. This term is somehow newly born and very few people are familiar with it. Although it is rarely used in people's daily communication, it is found that it is very common among university students and teenagers. Item 1 is among the items that scored the least levels of acceptability and readability. As Diagram 6 clearly shows, only two respondents with $10.5 \%$ considered this item highly acceptable and readable. Their explanations have pointed out that they had based their judgment on the context although they did not precisely understand the exact meaning of the Arabic verb (يُسنْنت) /ju:-səs-tım/. Derived from the noun system, the verb (يُسنسنم) [which literally translates into/to systematize/] is very common among the youth's daily conversations meaning that a boy keeps flirting his girlfriend the whole night time e.g., they talk about their desires and their wishes to fulfill their sexual and physical needs together.

Although the term, by default, is understandable in the given context, it has no relevant semantic connection with its original English meaning. Also, when it comes to translating this item into English, it will be challenging due to the lack of proper equivalence in English language. Here, although /ju:-səs-tım/is derived from English with a clear lexical meaning, we could not find any semantic relevance to the intended meaning of the original text. Therefore, competent translators and linguists might well get perplexed once they will provide a translation equivalence or a synonym for this intransitive verb.

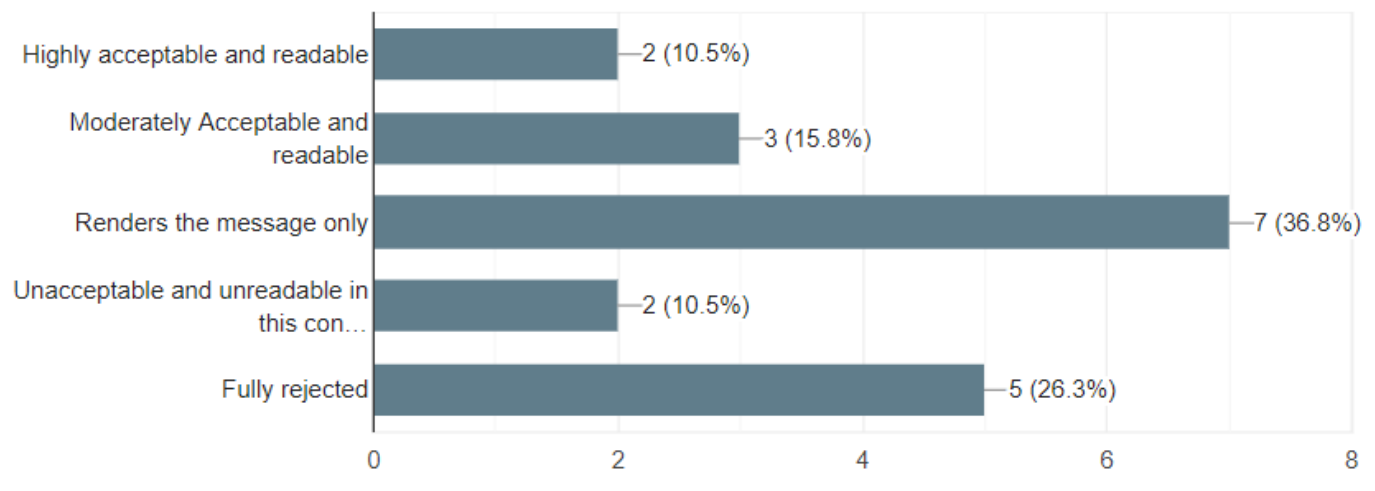

Diagram 6. Detailed responses for Item 1

\subsection{Unacceptability and Unreadability}

This stage of unacceptability and unreadability assumes that the local language will innately rejects any "foreignied segment," a notion Schleiermacher (2000) stressed. When any language includes aspects of two languages, it is expected to have what D'Ablancourt's termed "domesticized sense" by which he meant not to offend the delicacy of [the local] language by causing moral offense"(32-3). He explains that linguists shall disregard any foreign aspect within the local language even though it might be a source of "likeness" (53) Apparently, D'Ablancourt (2000) supports Schleiermacher who harshly criticizes linguists who employ, accept or approve the presence of foreign elements in a local text (53-4). Although D'Ablancourt and Schleiermacher referred to cultural and religious texts when theorizing about the necessity to have a domestic text, there exists a strong connection to text typology used in the present study whose items are observed in a bilingual community speech, whether at work, at home, or on the street.

As or the second category of discussion and analysis, we combined the last two criteria of the closed questionnaire (unacceptable and unreadable in the present context and fully rejected) to represent the state of unacceptability and unreadability as judged by the respondents of the study. This stage, as a matter of fact, corresponds to the previous one. It is axiomatic that the items that scored high levels of acceptability and readability will score a very low level of unacceptability and unreadability, so we will not go into a thorough analysis of this category. 
Table 2. Responses of unacceptable and unreadable Items

\begin{tabular}{|c|c|c|c|}
\hline The Context & 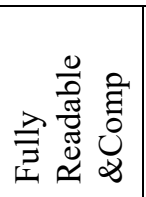 & The Context & 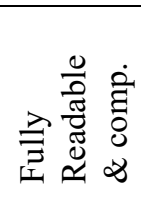 \\
\hline طي هويلنوطول للالبل (بيسنت)مع حيبته & 36.8 & لا تتسى (تسسيفي) اللي طبعتيه & 21 \\
\hline و اللهيامعلم لقيو اواحمكورنومتخبي & 36.8 & ايطاليا بلاد (الانتيكات) لازم نزور ها & 21.1 \\
\hline 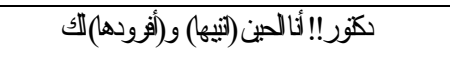 & 52.6 & و لا شارع (مسفلت).. كلها مكسرة. & 5.3 \\
\hline طولنهزه(يككن)مع الصبيا & 47.4 & روح لعند المالية الان (بكيشوك) & 15.8 \\
\hline بيو ان (البجت)مار احتنمح هنا العلم & 47.4 & هيوه موجود بالجامعه بس (يبركن) السيارة بيجي. & 36.9 \\
\hline . حكلي السكرنبيرة (كييه)و الشهابصنليق البربي. & 31.6 & اي مصطلح ما بتفهم معناه (غو غله). & 21 \\
\hline بي اروح (تثرج) للثلفن...ماضلىفيهرصيد & 31.6 & سيفه وحط الايقونه على (الدسك توب) & 15. \\
\hline ل لغرفة هني لازم(تنكش).ولجدم!! & 15.8 & كنت العب (قولجي) مع فريق الجامعة. & 15.8 \\
\hline لازمتزوحين طى (ييوتي ستر) & 10.6 & كمبازيونر كان نستخدم (السمارت بورد)... الان كله صسار & 15.8 \\
\hline لخوي ليوم(يزّ) على المريكا & 10.5 & مش لازم تمشي بالممر ات بدون (الماسك) & 15.8 \\
\hline لبعث ليمبلى للمدرسبين اللي غنلكو (سسيني) & 36.9 & معقولة يحسبولنا هذا الشغل (اوفر تايم). & 10.6 \\
\hline ـ الولدكن خلف من ابوه..شكاه مسكه (يككن)مع ببت & 26.6 & قبل ما يبلش الاجتماع تاكد من (السبيكرز) & 10.6 \\
\hline هو يحول أن (يؤلج) جميع ألافكر & 26.4 & مش قادر اقرأ الخط بتقدر تكبشرها ونتبعثلي اياها. & 57.9 \\
\hline
\end{tabular}

As table 2 clearly shows, there are two groups of responses towards the items which were considered unacceptable and unreadable by the respondents: high and low. High responses (57.9-36.9) represent the items that are fully rejected and are considered inappropriate within the context where they were mentioned. In contrast, low responses (36.9-5.3) stand for the percentages assembled in the three categories ("fully acceptable and readable", "moderately acceptable" and "only captures the message"). For example, item 26 [which translates into I can't read your handwriting. Can you capture it and forward it to me?] scored a very high percent of unacceptability and unreadability with 57.9\%. Similarly, it scored a very low level of acceptability and readability with 5.3\% which emphasizes the same point that the respondents did not feel its appropriateness within the context given (See Table 1). The phrase تكبشر ها /tkəp t/ir ha/ refers to the action of capturing or being captured and in the context given it is meant to take a screenshot, a snapshot or an image. As for the reason(s) why this item wasn't considered appropriate from the perspective of respondents is that it does sound heavy when uttered within an Arabic context. Further, others wondered why people shall use this item as long as there is a synonym that can be unaffectedly used. Some others thought of the term as a code-switching option while others described it as being "Arabeezy" [ A term coined from Arabic and English] and "creole". Apparently, the same applies to most of the items that have been Arabicized, creolized, borrowed with their English phonetic

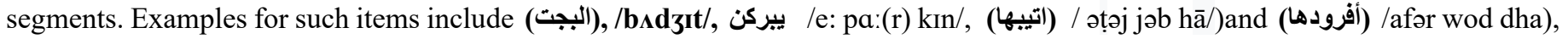
(اكبيها)/ ə kәp pi: ha:/...etc.

Diagram 7 below shows that the major reason for considering these items highly unacceptable is," Some people may not understand it" with $42.1 \%$ followed by "It reads and sound odd in an Arabic text" with $31.6 \%$. As they came to identify the reason(s) for their own choices based on the causes given to them, the respondents have consensually agreed to classify the items in table 2 as highly rejected. While some respondents attributed their choice to matters related to the distortion these items may cause to Arabic language contexts others pointed out to the inaccuracy of capturing the exact message of the original. 


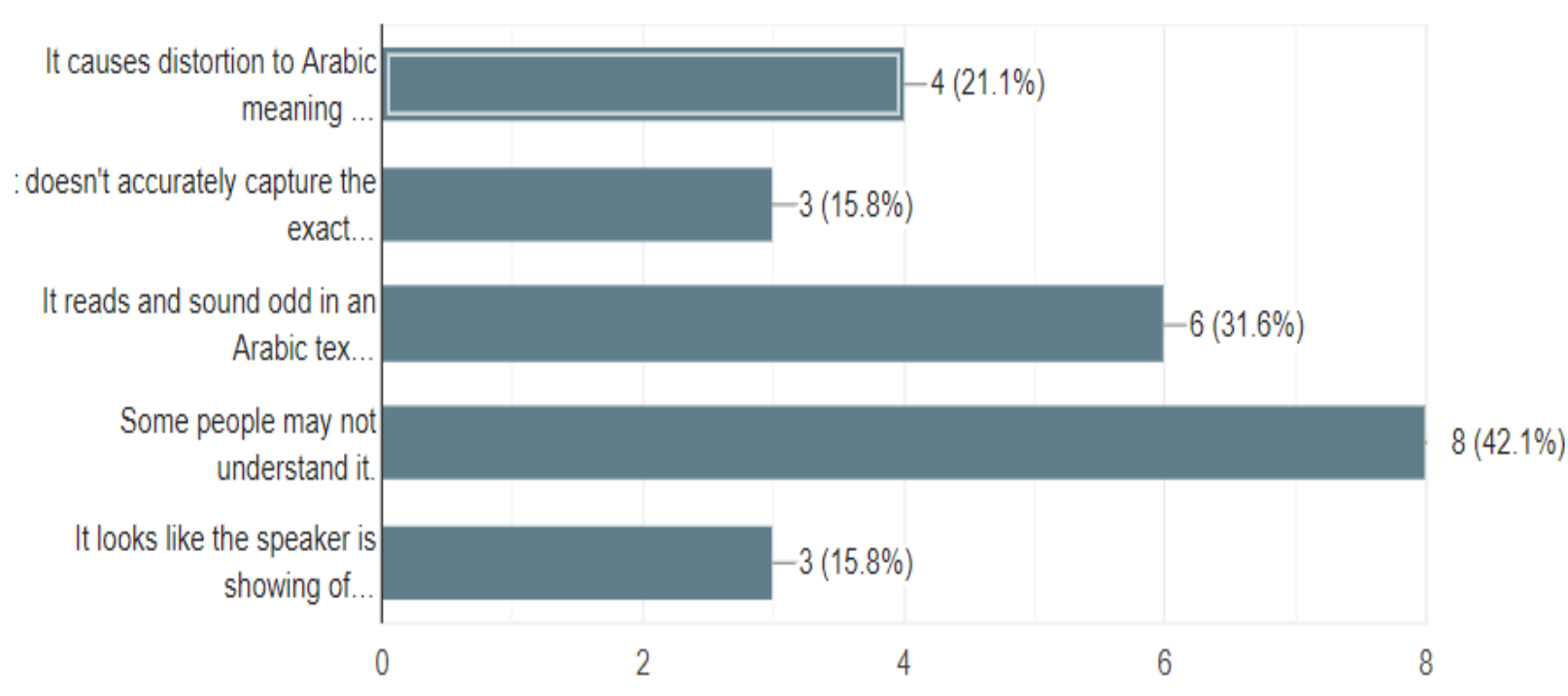

Diagram7. Analysis of respondents' choice

\subsection{Moderately Acceptable Items (Rendering the Message)}

It is very common in translation, interpretation and soft communication skills, in general, to observe that language users, translators and interpreters, whether belonging to target language or source language, ground their language on the communicative sense rather than the literalness of the original message or the word-by-word decoding their texts. As far as communication is concerned, linguists normally aim at rendering the intended message of the original text provided that they remain faithful to the original meaning in the source language text SLT. However, when it comes to the relatedness between communication and language shift the equation is different. Unlike communication, language shift among languages may well lead to language endangerment and language loss. According to Nida (1972) communication is there by nature and it helps people create animate existence through different signs, gestures and language mechanisms (309). Shehabat and Al-Zedanin (2012) explained that as soon as the original Arabic message maintains all elements of naturalness, then there is no harm done and the intended message will be rendered appropriately. However, when linguists and language users frequently opt for language shift they would definitely expose the local language to extinction and endangerment. This category of analysis involves the criteria of "moderately acceptable and readable" and "only renders the message." Table 3 below demonstrates the responses towards the items in the survey. 
Table 3. Responses of Moderately acceptable Items

\begin{tabular}{|c|c|c|c|}
\hline TheContext & 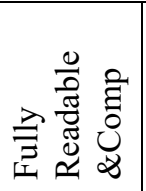 & The Context & 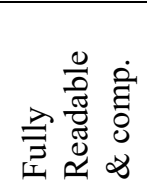 \\
\hline طي هويلنوطول اللبلى (بسنتر)مع حيبته & 52.6 & لا تتسى (تسسيفي) اللي طبعتيه & 42.1 \\
\hline و اللهيامعلم لقيو اواحدكورنومتخبي & 47.4 & ايطاليا بلاد (الانتيكات) لازم نزور ها & 42.1 \\
\hline ككور!! أنا لحين (نينيه) و(أفرودها)لك & 47.3 & ولا شارع (مسفلت).. كلها مكسرة. & 68.4 \\
\hline طولنهزه (يككن) مع الصبيا & 63.2 & روح لعند المالية الان (بكيشوك) & 89.5 \\
\hline بيلو لن (البجت)مار احتسمح هنا لعلم & 42.1 & هيوه موجود بالجامعه بس (ييركن) السيارة بيجي. & 57.9 \\
\hline . حكلي السكرنيرة (لكيبه)و الشهابصنليق البربد. & 52.1 & اي مصطلح ما بتفهم معناه (غو غله). & 73.7 \\
\hline بدي اروح (آثرج) الثلفون...ماضلىفيهرصيد & 63.2 & سيفه وحط الايقونه على (الدسك توب) & 47.4 \\
\hline . الغرفة هني لازم(تنكش).ولجدم!! & 52.6 & كنت العب (قولجي) مع فريق الجامعة. & 63.2 \\
\hline لازمتروحين طى (ييوتيستز) & 31.6 & كمبيوتز مان نستخدم (السمارت بورد).. الان كله صـار & 68.4 \\
\hline اخوي اليوم(يزي) على لمريكا & 21.1 & مش لازم تمشي بالممر ات بدون (الماسك) & 36.2 \\
\hline لبث ليمبلى للمدرسبين للي عنك و(سبني) & 73.7 & معقولة يحسبولنا هذا الشغل (اوفر تايم). & 47.4 \\
\hline ـالولدكلن خلف من لبو ه. شكاه مسكه (يككن)مع بنت. & 52.6 & قبل ما ييلش الاجتماع تاكد من (السبيكرز) & 79.3 \\
\hline هو يحلول أن (بؤلج) جميع ألافكل & 52.6 & مش قادر اقر أ الخط بتقدر تكبشر هاونتبعتلي اياها. & 36.8 \\
\hline
\end{tabular}

Ostensibly, the responses towards the criteria of moderately acceptable are significantly higher than the other two groups. The vast majority of responses range from $21.1 \%$ to $89.5 \%$, thus meaning that the major criterion the respondents took into consideration was that" it captures the message" and maintains the communicative value of the original items. Considering the nature of the semantic unit embedded within the item, it is axiomatic to conclude that the respondents embrace factors like communicative value of the text rather than purely delve into linguistic features that ensures capturing both the semantic denotative unit along with its communicative value.

Table 3 demonstrates that, contrary to the first two groups, these items have scored some high percentages. Item 17

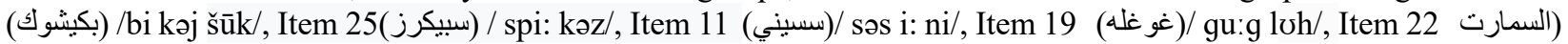
(/'sma:t , bo:d/...etc have all scored high percentages of being moderately acceptable with 89.5, 79.3, 73.7, 73.7, 68.4, respectively. Here, it is worth mentioning that these items have entered the daily communication of people due to the excessive use of digital language, referring to the information technology that prevailed among people, especially in the academic circles. In other words, we argue that they have become of a universal recognition.

As Diagram 8 below shows, the factor "It is easier and more communicative" scored the highest percentage while analyzing the respondents' choice. 12 respondents with $63.2 \%$ thought of the items in terms of their communicative value rather their linguistic, semantic or syntactic unit (See Diagram 8). Further, 7 respondents felt that the item sounds more expressive. However, none of the respondents felt that the speakers had resorted to using these items during their daily conversation in a way to look prestigious or stylish. Very few of them based their own choice on considering those items good synonyms and that they don't affect the original meaning. 


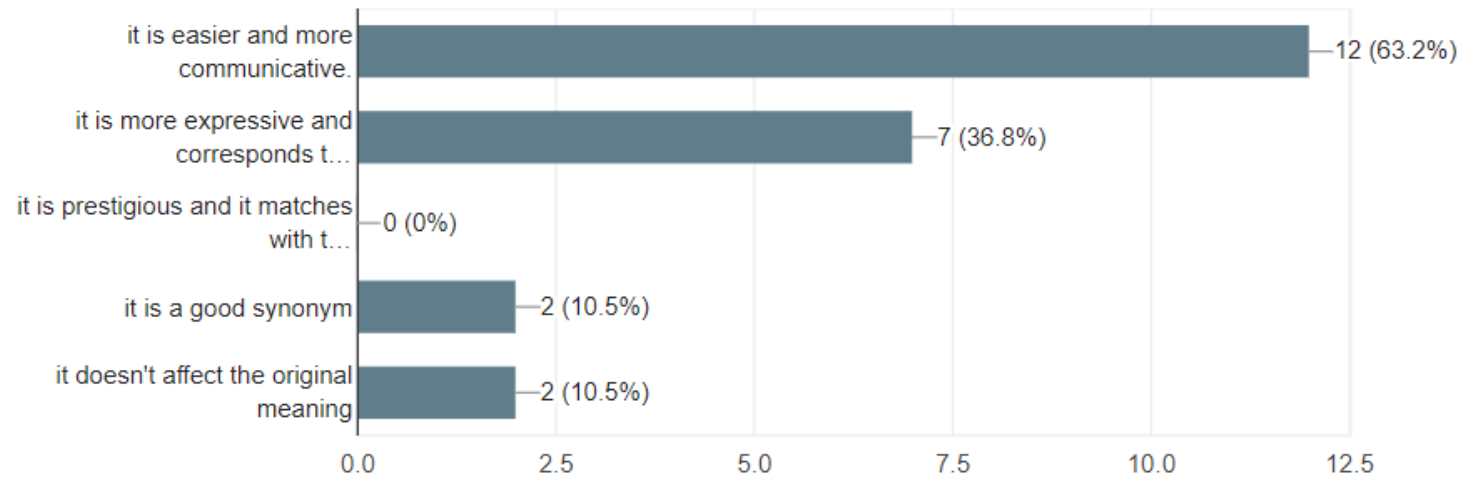

Diagram 8. Analysis of respondents' choice

\section{Conclusion}

A major conclusion that can be inferred from the current study is that most Arabic language specialists, even speakers, strongly refuse to mingle any other language with their mother tongue. Some have justified their responses by emphasizing the notion that Arabic language, being their local language and the respondents' mother tongue, should remain devoid of other linguistic predators from other dominant languages for the sake of being well-preserved. We found that there is a general tendency towards rejecting the items that have a foreignized sense unless the alternatives function similar to the original ones. In other words, the vast majority of the respondents have valued the expressions and terminologies that have a domesticized sense rather than the ones that are of foreignized sense. However, a number of subjects valued the responses that captured the communicative sense of the original message believing that they function better than any other unfamiliar expressions, even if it belongs to the local language. The current authors recommended that Arabic speakers are advised to abandon language shift in the presence of appropriate Arabic synonyms.

The fact that lots of foreign expressions have become widely used in Arabic conversation indicates that languages not only communicate and borrow expressions among each other but they also interact to facilitate the process communication, a point that has been highly stressed by scholars (e.g., Nida 1972, p. 313). However, due to the overuse of these expressions they started to cause a threat to Arabic language advocates and supporters. As far as this study is concerned, we have noticed that a great impact of code-switching has become factual in Arabic language due to the phenomenon of language shift.

\section{References}

Al-Ajrami, M. (2015). The Dilemma of Arabicization in the Arab World: Problems and Solutions. Theory and Practice in Language Studies, 5(10), 1989-1994. https://doi.org/10.17507/tpls.0510.03

D’Ablancourt, N. P. (2000). Preface to Tacitus. (Lawrence Venuti, Trans). The Translation Studies Reader. New York and London: Routledge.

De Corte F. (2003). The contribution of freelance translators, in Tosi A. (Ed.), Crossing barriers and bridging cultures: The challenges of multilingual translation for the European Union, Multilingual Matters, Frankfurt, pp. 67-72. https://doi.org/10.21832/9781853596704-008

Fishman, J. A. (1991). Reversing language shift: Theoretical and empirical foundations of assistance to threatened languages. Clevedon, UK: Multilingual Matters.

Grenoble, L. A., \& Whaley, L. J. (1998). “Toward a typology of language endangerment.” In L.A. Grenoble and L.J. Whaley (Eds.), endangered languages: language loss and community response. New York: Cambridge University Press, 22-54. https://doi.org/10.1017/CBO9781139166959.003

Hale, K., Krauss, M., Lucille, J., Akira, Y., Yamamoto, Colette, C., LaVerne, M., \& Nora, C. (1992). Endangered Languages. Language, 68(1), 1-42. https://doi.org/10.2307/416368

Kandler, A., \& Steele, J. (2017). Modeling Language Shift. PANS. 114(19), pp. 4851-5853. https://doi.org/10.1073/pnas.1703509114

Newmark, P. (1988). A Textbook of Translation, Prentice Hall, New York.

Nida, E.A. (1972). Communication and Translation. The Bible Translator, 23(3), 309-316. https://doi.org/10.1177/026009357202300303 
Priestly, T. (2003). Maintenance of Slovene in Carinthia (Austria): Grounds for guarded optimism? Can Slavon Pap 45, 95-117. https://doi.org/10.1080/00085006.2003.11092320

Salloum, H., \& Peters, J. (1996). Arabic Contributions to the English Vocabulary: English words of Arabic origin. Librairie du Liban Publishers, Beirut.

Schleiermacher, F. (2000). On the Different Methods of Translating. In Lawrence Venuti (ed.), the Translation Studies Reader (Susan Bernofsy, Trans.). New York and London: Routledge.

Shehabat, A., \& Al Zedanin, H. (2012). Sense-for-Sense Translation and the Dilemma of Comprehensibility in Translating Jordanian-Laden Proverbs: A Literary Perspective. CSCANADA, Studies in Literature and Language. 4(2), 29-35.

Thomason, \& Kaufman (1988). Language Contact, Creolization and Genetic Linguistics. USA: University of California Press.

Versteegh, K. (2001). Linguistic Contacts between Arabic and Other Languages. Arabic, 48(4), 470. https://doi.org/10.1163/157005801323163825

Appendix A

Below you will be provided with Arabic contexts where some unfamiliar words and/or expressions between brackets are given. All you need to do is to check the box that best represents your answer.

\begin{tabular}{|c|c|c|c|c|c|c|}
\hline The Context & 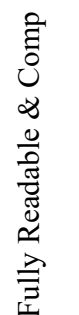 & 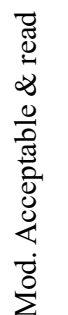 & 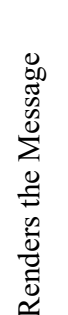 & 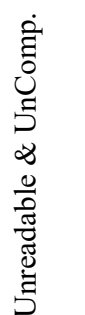 & 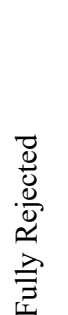 & $100 \%$ \\
\hline علي هو يان وطول الليل (يسنتم) مع حبييته & 10.5 & 15.8 & 36.8 & 10.5 & 26.3 & 99.9 \\
\hline و الله يا معلم لقيو او احد مكورن ومتخبي & 21.1 & 15.8 & 31.6 & 26.0 & 05.5 & 100 \\
\hline يا دكتور أنا الحين (اتيبها) و (أفرودها) للك & 5.3 & 10.5 & 36.6 & 36.8 & 10.8 & 100 \\
\hline طول نهاره (يكنكن) مع الصبايا & 10.5 & 21.1 & 42.1 & 15.8 & 10.5 & 100 \\
\hline يبدو ان (البجت) مار اح تسمح هذا العام & 10.5 & 10.5 & 31.6 & 31.6 & 15.8 & 100 \\
\hline حكتلي السكرتيرة (اكبيها) و ادشها بصناديق البريد. & 10.5 & 10.5 & 31.6 & 36.8 & 10.5 & 99.9 \\
\hline بدي اروح (انتشرج) التلفون...ما ضل فيه رصيد & 10.5 & 31.6 & 31.6 & 15.5 & 10.8 & 100 \\
\hline الغرفة هذي لازم (تتكندش). واجد حر & 31.6 & 26.3 & 26.3 & 10.5 & 5.3 & 100 \\
\hline لازم تُروحين على (بيوتي سنتر) & 21.1 & 42.1 & 26.3 & 5.3 & 5.2 & 100 \\
\hline اخوي اليوم (فيز) على امريكا & 57.9 & 10.5 & 21.1 & 0.0 & 10.5 & 100 \\
\hline ابعث ايميل للمدرسين اللي عندك و (سسيني) & 10.5 & 10.5 & 47.4 & 26.1 & 10 & 100 \\
\hline الولد كان خايف من ابوه.. شكله مسكه (يكنكن) مع بنت & 15.8 & 15.8 & 42.1 & 10.5 & 15.8 & 100 \\
\hline هو يحاول أن (يؤدلج) جميع ألافكار & 21.1 & 26.3 & 26.3 & 21.1 & 52 & 100 \\
\hline لا تنسى (تسسيفي) اللي طبعتيه & 36.8 & 26.3 & 15.8 & 10.5 & 10.5 & 99.9 \\
\hline ايطاليا بلاد (الانتيكات) لازم نزور ها & 42.1 & 31.6 & 10.5 & 10.85 & 5.3 & 100 \\
\hline .و لا شار ع (مسفلت).. كلها مكسرة & 26.3 & 42.1 & 26.3 & 0.0 & 5.3 & 100 \\
\hline روح لعند المالية الان (بكيشوك) & 5.3 & 68.4 & 21.1 & 5.2 & 00 & 100 \\
\hline ـ هيوه موجود بالجامعه بس (ييركن) السيارة بيجي & 15.8 & 26.3 & 31.6 & 10 & 16.3 & 100 \\
\hline اي مصطلح ما بتفهم معناه (غو غله) & 10.5 & 47.4 & 26.1 & 05.5 & 10.5 & 100 \\
\hline سيفه وحط الايقونه على (الدسك توب) & 42.1 & 26.3 & 21.1 & 10.5 & 0 & 100 \\
\hline كنت العب (قولجي) مع فريق الجامعة. & 21.1 & 47.4 & 15.3 & 5.3 & 10.5 & 99.6 \\
\hline كنازمان نستخدم (السمارت بورد).. الان كله صـار كميوتر & 26.3 & 36.8 & 31.6 & 0 & 5.3 & 100 \\
\hline مش لازم تمشي بالممر ات بدون (الماسك) & 21.1 & 31.6 & 31.6 & 5.2 & 10.5 & 100 \\
\hline معقولة يحسبولنا هذا الشغل (اوفر تايم) & 42.1 & 21.1 & 26.3 & 5.2 & 5.3 & 100 \\
\hline قبل ما يبلش الاجتماع تاكد من (السبيكرز) & 15.8 & 31.6 & 47.4 & 0 & 5.2 & 100 \\
\hline مش قادر اقرأ الخط بتقدر تكبشر هاونتبعثلي اباها. & 5.3 & 26.3 & 10.5 & 36.8 & 21.1 & 100 \\
\hline
\end{tabular}

\section{Copyrights}

Copyright for this article is retained by the author(s), with first publication rights granted to the journal.

This is an open-access article distributed under the terms and conditions of the Creative Commons Attribution license (http://creativecommons.org/licenses/by/4.0/). 